\title{
Efficiency Analysis of Restaurants Operating in the Rural Areas: The Case of Slovenia
}

\author{
Tanja Planinc \\ University of Primorska, Faculty of Tourism Studies - Turistica, Slovenia \\ tanja.planinc@fts.upr.si \\ Marko Kukanja \\ University of Primorska, Faculty of Tourism Studies - Turistica, Slovenia \\ marko.kukanja@fts.upr.si
}

The purpose of this paper is to analyse the efficiency performance of restaurants operating in the rural areas of Slovenia. The sample consisted of 52 independently run rural restaurant facilities. Data were obtained from restaurant managers and restaurant firms' financial reports. Based on a convenience sampling method, only those restaurants whose only source of operating revenues was providing food in a restaurant setting were included in the sample. In order to assess restaurants' efficiency performance, Data Envelopment Analysis (DEA) was used. Financial variables were used as inputs and outputs to perform DEA. This paper contributes to the growing body of literature in the field of restaurant efficiency measurement by providing valuable insights into rural-restaurants efficiency performance. The findings of this study have several significant implications for future research and practice.

Keywords: efficiency, restaurant industry, Slovenia, SMES, DE A

https://doi.org/10.26493/2335-4194.12.133-145

\section{Introduction}

Generally speaking, tourism is a vital economic activity and, in the previous decade, tourism achieved higher growth rates of gross domestic product in comparison to the world economy (w T TC, 2019b). In Slovenia, tourism plays a critical economic role. In 2018 , tourism contributed to more than $12 \%$ of national gross domestic product and offered employment to almost 13\% of all employees (w T T C, 2019a). Within the tourism industry, restaurants play an essential role. According to the official standard classification of activities in Slovenia, restaurants are a part of the category 'Food and beverage service activities,' which, together with accommodation activities, represents the main activity called 'accommodation and food service activities.' Food and beverage service activities are comprised of three subsectors (restaurants and mobile food service activities; event catering; beverage service activities) (see https://www.stat.si). The food and beverage sector is a vital part of the tourism industry, since tourists and visitors have to eat, and food is recognised as an indispensable tourism product. Approximately one-third of travel expenditure can be assigned to food consumption (Bélisle, 1983), and this figure can be even higher nowadays (Boyne, 2001).

A closer look at the Slovenian food and beverage sector reveals that in 2018, there were 6,597 business entities (5.4\% of all business entities), employing 18,622 employees (3.41\% of all employees). The largest and most important part of this sub-sector is restaurants and inns, which represent $55.87 \%$ of all business entities in the food and beverage sector (see http://www.ajpes.si). Consequently, this sub-sector is 
the focus of our research. In the food and beverage sector, most business entities earn revenues not only from the restaurant business but also from other activities (e.g., they also offer accommodation facilities). The restaurant sector is also characterised by monopolistic competition, low barriers to enter the business, demand volatility, and high fluctuation of employees (Lee, Hallak, \& Sardeshmukh, 2016). Since the focus of our analysis is the restaurant sector, only those restaurant facilities whose sole source of operating revenues presented the restaurant business were included in the study.

Rural areas are considered to be economically less developed regions (Roberts \& Hall, 2001) and, according to Dashper (2014), such areas are continually struggling with a decline in traditional economic activities (such as agriculture) and population (younger population is migrating to urban areas). Tourism is often seen as a tool to revive rural areas since it offers economic and social benefits that can boost rural development (George, Mair, \& Reid, 2009). Therefore, many governments see rural tourism as a remedy for rural areas and encourage its development in order to slow down or even reverse the negative trend of economic and social development (Briedenhann \& Wickens, 2004). A significant segment of tourism is rural tourism and, according to Roberts and Hall (2001), tourism in rural areas makes up to $20 \%$ of all tourism activity and more than $20 \%$ of European tourists choose rural areas as their holiday destination (ibid). Because of the low entry barriers, restaurant activity is a vital resource in rural development. Rural restaurants are also a crucial element in promoting local food and gastronomy heritage and also represent an essential element of income source for the local community (Bessière, 1998).

According to the Organisation for Economic CoOperation and Development's (OECD) definition of rural areas, the entire Republic of Slovenia is classified as a rural area. In addition, this definition distinguishes between two types of rural areas: predominantly and moderately rural regions (Ministrstvo za kmetijstvo in okolje, 2013). For the purpose of our research, the definition from the Geographical Terminological Dictionary (Geografski terminološki slovar, 2013) was used, since it defines rural areas as a cultivated landscape with agriculture and forestry as predominant economic activities, and with an above-average share of the rural population. According to Sedmak, Planinc, and Planinc (2011), this definition is more convenient when defining and identifying rural areas in Slovenia.

In order to contribute to the development of rural areas, tourism companies must perform efficiently. This means that firms have to produce 'a maximum output from a given set of inputs' (Farrell, 1957, p. 254). In academic literature, efficiency analysis in the field of tourism has gained popularity in the previous century (since 1950). The majority of studies are concerned with the lodging sector (Poldrugovac, Tekavcic, \& Jankovic, 2016; Barros, Dieke, \& Santos, 2010; PérezRodríguez \& Acosta-González, 2007; Barros \& Santos, 2006; Brown \& Ragsdale, 2002), while the restaurant sector is somehow neglected (Planinc, Kukanja, \& Planinc, 2018; Alberca \& Parte, 2018; Kukanja \& Planinc, 2018b; Reynolds \& Biel, 2007) although it is a vital part of the tourism industry.

The main research objective of this paper was to determine the efficiency level of restaurants located in Slovenian rural areas and to provide suggestions for the decision-makers in order to improve their operational efficiency. The second research objective was to analyse if there are statistically significant correlations between restaurants' physical characteristics and operational efficiency.

\section{Literature Review}

There are numerous expressions that describe rural tourism, such as 'agritourism, farm tourism, soft tourism, alternative tourism, ecotourism, and others (Sharpley \& Sharpley, 1997, p. 9). The OECD (1994) suggested that rural tourism should be located in rural areas, sustainable, connected with local inhabitants, developed on a small scale and, most importantly, it should be used in a way to conserve the rural natural and cultural environment. The term 'rural tourism' has also been adopted by the European Community to refer to all tourism activity in rural areas (Roberts \& Hall, 2001).

Rural tourism offers many potentials benefits for 
rural areas. These benefits can be grouped into three segments: economic, social, and environmental (MacNulty, 2004). Generally speaking, jobs in the tourism sector do not require high education or advanced training and consequently, tourism can be an essential element in providing employment for local residents with lower education (Nigam \& Narula, 2011). Job opportunities also arise from the fact that, especially in the restaurant industry, there are low barriers to entry into the business market (Assaf, Deery, \& Jago, 2011). In addition, tourism also improves local quality of life through investments in infrastructure and is an important source of local tax revenues (Nigam \& Narula, 2011). As far as environmental benefits are concerned, rural tourism plays a vital role in protecting the natural and cultural environment (MacNulty, 2004). Food expenditures are an essential part of tourists' and visitors' budgets, and this is something restaurants in rural areas should be aware of. In addition, restaurants in rural areas offer a link between local gastronomy and culture and can, therefore, be a vital promotion tool of a rural destination image (Boyne, Williams, \& Hall, 2002).

Regardless of the well-acknowledged importance of rural tourism, Hall, Roberts, and Morag (2016) pointed out that rural areas, in general, will gain maximum benefit from tourism only when it is engaged as one part of actions to revive such areas. In the case of a weak economy and social degradation, tourism can additionally contribute to income inequality. Nevertheless, although rural tourism is unable to solve the problems of all rural areas, it still offers numerous possibilities for economic growth and development (Dashper, 2014).

According to Farrell (1957, p. 254), a firm is efficient, when it produces 'maximum output from a given set of inputs.' In operational efficiency measurement, we compare the observed (actual) and the optimal values of input(s) and output(s). If the optimal values are identified in terms of production possibilities, then the efficiency is defined as technical. In contrast, if the optimal values are identified thru firm's behavioural goals (in terms of cost, revenue, and profit), the efficiency is defined as economic (Fried, Knox Lovell, \& Schmidt, 2008).
Traditionally, firms have used partial ratio analysis in order to estimate their operational efficiency and to perform a benchmark analysis with competitors (Riley, 1999). Despite its ability to quickly assess the firms' performance, the usage of ratios has several limitations, including the fact that it only uses two static variables.

Consequently, there was a growing need for a more thorough approach to efficiency analyses since firms use multiple inputs to produce multiple outputs simultaneously (Donthu, Hershberger, \& Osmonbekov, 2005). As a result, the efficiency of frontier approaches was developed. There are two groups of frontier methods to estimate firms' operational efficiency, parametric and nonparametric frontier approaches (Bogetoft \& Otto, 2011). With parametric methods (such as stochastic frontier analysis (SFA)), there is a need of a pre-specification of the functional form in the estimation of production frontier technologies (Assaf \& Agbola, 2011), whilst nonparametric methods (such as DEA) are not so strict. DEA forms a production frontier of best practices and enables the calculation of efficiency scores for each observed unit (Oliveira, Pedro, \& Marques, 2013). An observed unit is $100 \%$ efficient (and therefore lies on the frontier) when no output can be increased without increasing its inputs (Wöber, 2007). An efficiency score of less than $100 \%$ indicates that the observed unit is inefficient. Efficiency measurement using frontier analysis is a quite useful and valuable tool in determining critical areas of cost control (Assaf \& Matawie, 2009). The most crucial benefit of frontier analyses is that they reveal the gap between a firm's actual and optimal performance. In addition, frontier analyses are able to combine multiple inputs and outputs simultaneously. This cannot be said for the traditional methods of performance measurement (accounting-based ratios, cost, volume profit analysis, etc.), although they are still commonly used in assessing firms' operational performance.

The abovementioned advantages are the main reason for the rapid growth of academic literature on performance measurement with efficiency frontier analyses (Assaf \& Josiassen, 2016). In the last decade, the use of DEA has become quite popular for assessing the relative efficiency of business entities (Martić, Novaković, 
\& Baggia, 2009). In addition, DEA has proved to be a reliable tool for assessing efficiency in various business fields (Emrouznejad \& Yang, 2018). DEA combines multiple inputs and outputs simultaneously, and it also allows the usage of controllable (within managers' influence) and uncontrollable variables (managers have no influence on these variables). Requisite assets (goods and material used, services, labour, tangible and intangible assets) are controllable inputs, and no business entity can operate without them. Therefore, it is vital for managers to know how efficiently they are using them in achieving operational efficiency. In this view, the requisite assets represent a solid starting point for evaluating a firm's operational efficiency.

Efficiency analyses in academic literature in the field of tourism has gained popularity since the late 1980 os and, according to Wöber (2007), 35 studies of tourism efficiency with DEA were published in the period from 1985-2006. Sainaghi, Philips, and Zavarrone (2017) performed a content analytical meta-approach on performance measurement in tourism. Most researchers studied the efficiency of the lodging industry, while the restaurant sector was somehow neglected (although it is a vital part of the hospitality industry). Their study included almost 1,00o scientific papers, and the efficiency measurement appeared in 170 papers with a first jump in the volume of paper in the period from 2007-2010 and a second jump in the period from 2011-2014.

In the academic literature, there is a growing body of studies related to the efficiency measurement using DEA in the restaurant industry (see also Table 1). The first study dates to 1986, when Hrusckha used the panel database on an aggregated level. He applied DEA analysis for ten restaurant groups and determined differences in efficiency among them (Hruschka, 1986). In the same year, Banker and Morey used the same method on a chain of fast-food restaurants (6o restaurants). They introduced the idea to use some uncontrollable inputs (age of the restaurant, location, etc.) when determining the efficiency scores. In their model, they modified the input constraints in a way to disallow the reduction of uncontrollable inputs. The result of their analysis suggested that differ- ent assumptions about controllable and uncontrollable inputs have a significant impact on efficiency results. When all inputs were considered to be controllable, 24 restaurants were efficient, but when some inputs were considered to be uncontrollable, 32 restaurants achieved efficiency score 1 . The fixed nature of uncontrollable inputs allows the identification of opportunities for targeted savings in all controllable inputs that are used in the analysis (Banker \& Morey, 1986).

Then, after almost two decades, researchers rediscovered DEA in the restaurant industry and, in the last five years, the number of studies intensified (see Table 1). Some studies have focused on the efficiency of menu items in order to improve restaurant firms' financial performance. Taylor, Reynolds, and Brown (2009) employed DEA as an analytic technique for analysing menu-item efficiency. They analysed 65 menu items in three full-service restaurants and concluded that menu items that are selected with DEA yield higher gross profit. However, their results were not validated, since the study was performed as a simulation. Fang and Hsu (2014) analysed 30 menu items in two restaurants of the same branded chain and proved that menu items selected with DEA increase the profitability of both restaurants by more than $15 \%$ compared with the traditional menu-engineering method.

Nevertheless, most studies were concerned with the operational efficiency of restaurants within the same franchise or chain. Reynolds (2004) analysed the efficiency of 38 same-brand restaurants and determined that seven restaurants achieved an efficiency score of 1 and that restaurants with the highest sales were not the most efficient. Reynolds and Thompson (2007) analysed the efficiency of a chain of 60 full-service restaurants; they determined that seven restaurants operated efficiently, and the average efficiency score for all 60 restaurants was $82 \%$. Reynolds and Biel (2007) analysed the efficiency of a chain of 36 casual-theme restaurants where the average efficiency score was $86 \%$, and eight restaurants achieved an efficiency score of 1 . They determined that with more efficient use of inputs, the restaurants' income could be increased by $13.4 \%$. Hadad, Friedman, and Hanani (2007) analysed data from 30 restaurants. They used 
various DEA models and consequently obtained two different sets of efficiency scores. According to the first scenario, seven restaurants were fully efficient; according to the second scenario, 11 restaurants achieved an efficiency score of 1 . The emphasis of their research is on the comparison of different ranking methods (e.g., restaurant rankings in restaurant guides) with the results of DEA.

Giménez-García, Martínez-Parra, and Buffa (2007) performed a DEA analysis with the data of 54 Spanish fast-food restaurants. According to the analysis, due to input reallocation, sales and service quality can be increased on average by $4.20 \%$. Roh and Choi (2010) employed DEA analysis to evaluate the efficiency of three brands within the same restaurant franchise. The sample consisted of 136 restaurants, and the efficiency was assessed based on interviews with managers. The analysis revealed that the average efficiency score is $73 \%$ and that the efficiency results of each brand differ significantly from the others. In some cases, it was determined that the restaurant size and managers' experience have a positive and statistically significant impact on efficiency scores, meaning that larger restaurants with more experienced managers achieve higher efficiency scores (Assaf et al., 2011). Kukanja and Planinc (2018a) used secondary financial data to analyse the efficiency of 142 restaurants. The average efficiency score was $85 \%$, and 23 restaurants were fully efficient. Labour costs and depreciation proved to be the main areas for efficiency improvement.

Some researchers used panel data in determining the efficiency over a specific time period. For example, Giokas, Eriotis, and Dokas (2015) analysed the efficiency of 21 Greek restaurant companies in prerecession and recession and recovery periods (20062012). The results reveal that the average efficiency scores are $0.85,0.80$, and 0.80 and that most companies had no significant change in their efficiency while three companies had a significant efficiency decrease. Mhlanga (2018) analysed the efficiency of 16 South African restaurants in a four year period (20122016). Four restaurants achieved an efficiency score of 1 at some point in the four-year period. Full-service restaurants have higher efficiency scores in comparison to fast food and casual restaurants.
In addition, the location and revenue per available seat have a statistically significant positive impact on restaurants' efficiency. Parte and Alberca (2019) examined the efficiency of 1,071 Spanish bar companies for the 2005-2014 period. The mean efficiency scores ranged from 0.673 in 2005 to 0.711 in 2014. Companies improved their efficiency through reducing inputs (the number of employees, labour costs and operational costs). The results also revealed the levels of employees' education and employment rate are significantly and positively correlated with efficiency. In contrast, low wages and long working hours are significantly and negatively correlated with efficiency.

Efficiency studies in the period from 1986 to 2019 are presented in Table 1. Most studies used sales revenues as an output in the analyses. However, there is much more inconsistency when it comes to the selection of inputs. Consequently, the efficiency results of the presented studies are not fully comparable. This would not be the case if there were a standardised selection of inputs and outputs, as in some other business sectors, such as banking. Assaf and Josiassen (2016) also concluded that the selection of inputs and outputs is driven mainly by data availability rather than theoretical arguments. Efficiency scores of restaurant firms from previous studies vary from $46.17 \%$ (Assaf et al., 2011) up to 86\% (Reynolds \& Biel, 2007). Efficiency scores vary because of differences in the variables, different characteristics of restaurant firms, and because researchers used different models of DEA. Specifically, several authors (Reynolds, 2003; Roh \& Choi, 2010; Assaf et al., 2011) emphasised the importance of correlation analyses between inputs and outputs before performing DEA. Interestingly, the analysis of studies presented in Table 1 reveals that most studies do not provide any evidence of correlation analyses between inputs and outputs. The only exceptions are the studies of Reynolds and Biel (2007), Reynolds and Taylor (2011), Roh and Choi (2010), Taylor et al. (2009), and Kukanja and Planinc (2018a). In addition, researchers use different DEA models within the same research without proper theoretical justification for such action.

Therefore, we decided to use requisite assets as variables in our research, since no business entity can 
Table 1 Efficiency Studies in the Restaurant Industry

\begin{tabular}{|c|c|c|}
\hline Authors & Inputs & Outputs \\
\hline Hruschka (1986) & $\begin{array}{l}\text { No. of seats, labour costs, costs of goods sold, other } \\
\text { operating expenses }\end{array}$ & Sales \\
\hline Banker and Morey (1986) & $\begin{array}{l}\text { Costs of goods sold, labour costs, age of the restaurant, } \\
\text { advertising expenditures, location, existence of a 'drive-in' } \\
\text { window }\end{array}$ & Sales \\
\hline Reynolds (2003) & No. of labour hours & Sales \\
\hline Reynolds (2004) & $\begin{array}{l}\text { No. of labour hours, average salary, no. of seats, no. of } \\
\text { competitors }\end{array}$ & Sales, tips \\
\hline $\begin{array}{l}\text { Reynolds and Thompson } \\
(2007)\end{array}$ & Average salary, no. of seats & Sales, tips \\
\hline Reynolds and Biel (2007) & $\begin{array}{l}\text { Costs of goods sold, labour costs, employee satisfaction, no. } \\
\text { of seats, taxes and insurance }\end{array}$ & Profit, retention equity \\
\hline $\begin{array}{l}\text { Hadad, Friedman and Hanani } \\
(2007)\end{array}$ & $\begin{array}{l}\text { No. of seats, no. of all employees, no. of employees in a } \\
\text { shift, total size }\end{array}$ & $\begin{array}{l}\text { Average no. of guests per day, } \\
\text { average selling price }\end{array}$ \\
\hline $\begin{array}{l}\text { Giménez-García, } \\
\text { Martínez-Parra and Buffa } \\
(2007)\end{array}$ & $\begin{array}{l}\text { No. of all employees, seats and server, no. of competitors, } \\
\text { average spending per guest }\end{array}$ & Sales, service quality \\
\hline $\begin{array}{l}\text { Taylor, Reynolds, and Brown } \\
\text { (2009) }\end{array}$ & Meal method preparation, no. of purveyors, no. of stations & Gross profit, meal popularity \\
\hline Roh and Choi (2010) & $\begin{array}{l}\text { Total size, hall size, kitchen size, no. of seats, no. of tables, } \\
\text { no. of all employees, no. of kitchen and hall, monthly salary } \\
\text { and rent, overhead expenses }\end{array}$ & Sales, net income \\
\hline Assaf, Deery, and Jago (2011) & No. of seats, no. of employees, food and beverage costs & $\begin{array}{l}\text { Sales from food, sales from } \\
\text { beverages }\end{array}$ \\
\hline Fang and Hsu (2014) & Labour costs, costs of goods sold, no. of purveyors & Gross profit, meal popularity \\
\hline $\begin{array}{l}\text { Giokas, Eriotis and Dokas } \\
(2015)\end{array}$ & $\begin{array}{l}\text { Operating expenses (without costs of goods sold), assets } \\
\text { value }\end{array}$ & Sales \\
\hline Mhlanga (2018) & $\begin{array}{l}\text { No. of employees, no. of seats, labour costs, other operating } \\
\text { expenses }\end{array}$ & Sales, no. of covers \\
\hline Kukanja and Planinc (2018a) & $\begin{array}{l}\text { Labour cost, depreciation, costs of goods sold, costs of } \\
\text { services }\end{array}$ & Sales \\
\hline Alberca and Parte (2018) & Labour costs, other operating expenses, assets value & Sales \\
\hline Parte and Alberca (2019) & $\begin{array}{l}\text { No. of employees, labour costs, other operating expenses, } \\
\text { assets value }\end{array}$ & Sales \\
\hline
\end{tabular}

operate without them. It is also necessary for managers to know how efficiently they are using them in achieving operational efficiency. In this view, the requisite assets present a solid starting point for evaluating a firm's operational efficiency.

\section{Research Methodology}

In order to acquire primary data, a questionnaire was developed based on previous studies on efficiency measurement in the restaurant industry (presented in Table 1). The questionnaire consisted of two parts; the 
first was concerned with the socio-demographic characteristics of managers (gender, age, education, working experience), while the second dealt with the characteristics of restaurants (size, number of seats, employees, competitors, etc.). Secondary data consisted of financial data for the year 2018 (net sales revenues; acquisition cost of goods and material sold and costs of material; costs of services; labour costs; depreciation). Financial data were obtained by the Agency of the Republic of Slovenia for public legal records and related services (http://www.ajpes.si). The availability of official financial data is a significant advantage of our research since we can avoid the subjective opinions of restaurant managers on financial matters.

In order to achieve the main objective of this research, data were gathered from 52 restaurant facilities, located in rural areas in three municipalities in the country with the highest number of overnight stays (Ljubljana; Piran; Bled). The oecD definition classification of Slovenian rural areas was not useful for defining the sample for our research. Therefore, we used the definition from the Geographical Terminological Dictionary (Geografski terminološki slovar, 2013), as already explained in the Introductory chapter.

Barrows, Vieira, and DiPietro (2015) recommended being cautious in identifying the competitive set for the benchmarking process. Therefore, we included restaurant facilities which are similar according to their operating variables. Restaurant facilities had to be officially classified as restaurants and inns; had to be run independently, and the restaurant activity had to be the only source of restaurants' operating revenues. Based on the convenience sampling method, we selected 250 business entities. All of them were prechecked in extensive field research. Fieldwork was conducted by ten interviewers during the summer and autumn of 2018. Only those facilities that met all the above-mentioned criteria were included in the study. According to interviewers' feedback, many managers refused to participate in our research for a variety of reasons. In the end, the final sample consisted of 52 independently-run restaurant facilities.

The demographic data of managers and physical characteristics of restaurants were analysed with the spss 24 software. In order to determine the effi-
Table 2 Correlation Coefficients between Inputs and Output

\begin{tabular}{|c|c|c|c|c|}
\hline (1) & (2) & (3) & (4) & (5) \\
\hline Pearson Corr. & $0.980^{* *}$ & $0.831^{\star *}$ & $0.962^{* *}$ & $0.777^{\star *}$ \\
\hline Sig. (2-tailed) & $0.000^{* *}$ & $0.000^{* *}$ & $0.000^{* *}$ & $0.000^{* *}$ \\
\hline \multicolumn{5}{|c|}{$\begin{array}{l}\text { Notes }{ }^{* *} \text { Correlation is significant at the o.o1 level (2- } \\
\text { tailed). Column headings are as follows: (1) net sales rev- } \\
\text { enues, (2) acquisition cost of goods and material sold and } \\
\text { costs of material, (3) costs of services, (4) labour costs, (5) } \\
\text { depreciation. }\end{array}$} \\
\hline
\end{tabular}

ciency levels, we conducted a DEA analysis with the software DEAP version 2.1. We opted for an inputoriented DEA model since restaurant managers have a much higher influence on the inputs than on the outputs (Mhlanga, 2018) and, in such a robust competitive environment, firms are usually input-oriented (Barros, 2005). In addition, input-oriented models are a measure of competitiveness (Oliveira et al., 2013). In the input-oriented model, we want to determine by how much the input(s) can be reduced without changing the output(s) (Coelli, Rao, O'Donnell, \& Battese, 2005). We also used the constant returns to scale (CRS) option, since in the restaurant industry there is a strong monopolistic competition and all firms have the possibility of operating at an optimal and similar scale (Coelli et al., 2005). The efficiency scores were calculated based on one output (net sales revenues) and three inputs (acquisition cost of goods and material sold and costs of material, costs of services, labour costs, and depreciation). Prior to calculating the efficiency scores, it is necessary to verify that all inputs were correlated with the output. The results are presented in Table 2.

\section{Results and Discussion}

Firstly, we analysed the demographic data of managers and the physical characteristic of restaurant facilities. The results are presented in Table 3. The analysis of the data revealed that there were slightly more male respondents (51.9\%) than females (48.1\%) and the average age of the respondents was 45.15 years. Most (8o.8\%) respondents had a high-school education, and all the rest (19.2\%) achieved a college or faculty degree. 
Table 3 Socio-Demographic Data of Managers

\begin{tabular}{|c|c|c|c|}
\hline Variable & Item & $f$ & $\%$ \\
\hline \multirow[t]{2}{*}{ Gender } & Female & 25 & 48.10 \\
\hline & Male & 27 & 51.90 \\
\hline \multirow[t]{5}{*}{ Age } & $16-25$ & 2 & 3.85 \\
\hline & $26-35$ & 8 & $15 \cdot 38$ \\
\hline & $36-45$ & 14 & 26.92 \\
\hline & $46-55$ & 20 & 38.46 \\
\hline & More than 55 & 8 & $15 \cdot 38$ \\
\hline \multirow{4}{*}{$\begin{array}{l}\text { Level of } \\
\text { education }\end{array}$} & Elementary school & $\mathrm{o}$ & 0.00 \\
\hline & Vocational or secondary school & 42 & 80.80 \\
\hline & College/faculty degree & 10 & 19.20 \\
\hline & Master's degree or $\mathrm{PhD}$ & $\mathrm{o}$ & 0.00 \\
\hline \multirow{5}{*}{$\begin{array}{l}\text { Working } \\
\text { experience }\end{array}$} & $0-10$ & 9 & $17 \cdot 31$ \\
\hline & $11-20$ & 13 & 25.00 \\
\hline & $21-30$ & 19 & 36.54 \\
\hline & $31-40$ & 9 & $17 \cdot 31$ \\
\hline & More than 40 & 2 & 3.85 \\
\hline \multirow{2}{*}{$\begin{array}{l}\text { Ownership } \\
\text { structure }\end{array}$} & Owner and manager & 43 & 82.70 \\
\hline & Manager & 9 & 17.30 \\
\hline
\end{tabular}

Table 4 Restaurants' Characteristics

\begin{tabular}{lrr}
\hline Variable & $(1)$ & $(2)$ \\
\hline Size of the restaurant $\left(\mathrm{m}^{2}\right)$ & 248.50 & 102.15 \\
Number of seats & 136.08 & 46.13 \\
Number of employees & 6.38 & 4.04 \\
Age of the restaurant & 38.24 & 25.42 \\
Number of competitors & 1.42 & 1.02 \\
Average spending per guest in EU R & 13.87 & 5.11 \\
\hline
\end{tabular}

Notes Column headings are as follows: (1) mean, (2) standard deviation.

As far as working experience in the restaurant industry is concerned, managers had, on average, almost 23 years of working experience. The majority of respondents $(82.7 \%)$ owned the restaurant facility and were also employed as managers, while the rest $(17.3 \%)$ were only managers.

In the next step, we analysed the characteristics of restaurants facilities. The results are presented in Table
Table 5 Financial Data in Euros

\begin{tabular}{lrr}
\hline Variable & $(1)$ & $(2)$ \\
\hline $\begin{array}{l}\text { Acquisition cost of goods } \\
\text { and material sold and costs }\end{array}$ & $102,866.46$ & $67,946.77$ \\
of material & & \\
Costs of services & $26,512.27$ & $12,974.09$ \\
Labour costs & $57,267.40$ & $37,630.60$ \\
Depreciation & $6,655.67$ & $2,930.96$ \\
Net sales revenues & $213,347.77$ & $105,756.92$ \\
\hline
\end{tabular}

Notes Column headings are as follows: (1) mean, (2) standard deviation.

4. The analysis of restaurant facilities characteristic indicated that the average size of a restaurant was 248.5 square metres and the average number of seats was 136. In terms of the number of employees, more than half of all restaurants included in the sample $(51.92$ $\%$ employed up to 5 employees, $32.70 \%$ employed from 6 to 10 employees, and only three restaurants (5.77\%) employed more than 15 employees. On average, the restaurants had been in business for 38 years, and $78.8 \%$ of them were run as family businesses.

As suggested by Reynolds (2004), we also gathered information on the number of competitors in the vicinity of a restaurant facility. Almost half of the restaurants ( $46.15 \%$ ) had o or 1 competitors, while all the rest $(53.84 \%)$ had 2 or 3 competitors within a $1 \mathrm{~km}$ radius. The average spending per guest (person - ASP) in all restaurants was almost 14 euros.

Next, we analysed the financial data of all 52 restaurant facilities for the year 2018. As already mentioned, the financial data form statements of income were obtained from national authorities. The results are presented in Table 5.

According to the results presented in Figure 1, only nine restaurant firms achieved a score of 1 , which indicates that they are fully efficient $(100 \%)$. The average value of efficiency of all 52 firms under observation is $67 \%$. Based on research results, we can conclude that on average, the evaluated firms could reduce their inputs by $33 \%$ and simultaneously maintain the same level of total sales revenues (the output). Detailed results on efficiency scores are presented in Figure 1.

Twenty-nine restaurants achieved and efficiency 


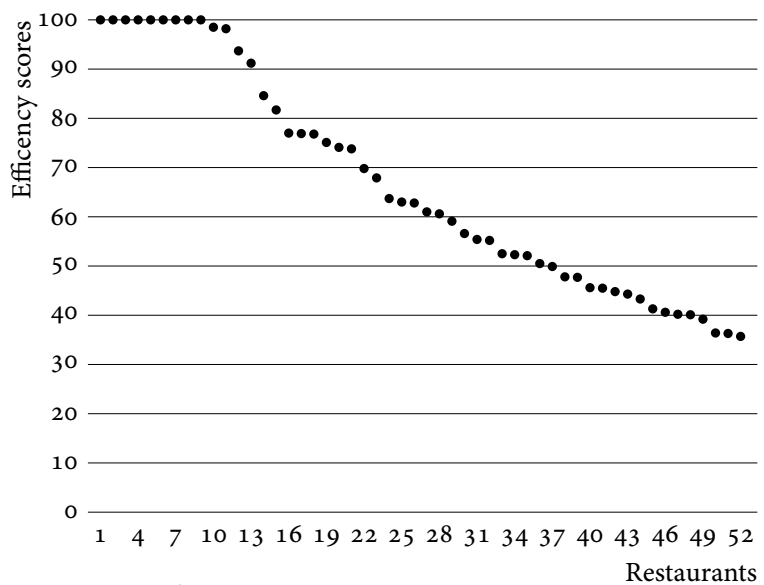

Figure 1 Efficiency Scores

score below the average efficiency score, while 23 restaurants achieved above the average efficiency. Detailed analysis of restaurants that had achieved the efficiency score below the average revealed that when it comes to the input 'costs of labour', there is much room for optimisation. This is also true for other inputs but to a lesser extent. According to the analysis, the costs of labour could be, on average, lower by more than $60 \%$. Although all requisite assets are controllable inputs, managers cannot lower them to the recommended extent. Because of already low salaries in the restaurant industry (see explanation below) and also due to the Slovenian tax legislation, managers cannot afford such a drastic cost reduction. The average monthly gross salary in the restaurant industry for the year 2018 in Slovenia was $€ 1,056.22$, while the average gross salary for all business subjects was $€ 1,681.55$ (see https://pxweb.stat.si). The actual net salaries in Slovenia are lower by more than $30 \%$ due to relatively high tax burdens. Consequently, restaurant managers have little or no space in terms of labour cost reductions.

Another significant issue is concerned with the lack of people willing to work in the restaurant industry. The Slovenian government addressed this issue by changing the legislation in 2005 by eliminating the condition of mandatory education for professions in the tourism and restaurant industry (waiters, cooks, receptionists, etc.) (Zakon o spremembah in dopolnitvah Zakona o gostinstvu, 2005). The change in legislation did not bring the desired effect. According to
Table 6 Correlation Coefficients between Efficiency Scores and Restaurants' Physical Characteristics

\begin{tabular}{lrrrr}
\hline$(1)$ & $(2)$ & $(3)$ & $(4)$ & $(5)$ \\
\hline Pearson Corr. & -0.214 & -0.252 & -0.222 & $-0.279^{*}$ \\
Sig. (2-tailed) & 0.127 & 0.072 & 0.114 & 0.045 \\
\hline
\end{tabular}

Notes ${ }^{\star}$ Correlation is significant at the 0.05 level (2-tailed). Column headings are as follows: (1) efficiency scores, (2) restaurant size, (3) no. of seats, (4) average spending per person, (5) age of a restaurant.

Zupančič (2019), the government should take some steps in reducing the tax burden on salaries which would result in higher net salaries.

Regarding the cost of goods and material sold and costs of material, managers should consider optimising costs through inter-firm networking. According to Sedmak et al. (2011), there are still unexploited potentials in networking between firms in the Slovenian hospitality sector, as research results revealed that managers see the inter-firm networking as a possibility to gain access to more reliable and favourable suppliers.

Next, we verified whether there are correlations between efficiency scores and restaurants' physical characteristics, which would help us to better understand the efficiency level in rural restaurant facilities. We considered the size of a restaurant, the number of seats, the average spending per guest, and the age of restaurants. The results are presented in Table 6 .

The results of the correlation analysis showed that only the age of restaurants has a weak negative statistically significant correlation with the efficiency scores $(r=-0.279,2$-tailed Sig. $=0.045)$. Although the correlation coefficients do not indicate the direction of causality, we might assume that restaurants operating for a more extended period of time are becoming less efficient. One possible explanation could be that restaurants in their early life cycle stages put more effort in marketing actions in order to become recognisable than in their maturity and decline phase, which results in higher operational efficiency (on average restaurants have 38 years of business activity). Nevertheless, further research should be undertaken to investigate the influence of different life cycle stages 
and years of business activity on restaurants' operational efficiency.

\section{Conclusion}

The primary goal of this paper was to determine the efficiency of selected restaurants operating in rural areas. We decided to use the requisite assets as inputs since no business can operate without them. According to the analysis, the selected restaurants achieved an average efficiency score of $67 \%$. This result is not in line in comparison with other studies of restaurant efficiency, where the identified efficiency results were higher (Banker \& Morey, 1986; Choi, Roh, \& Yoon, 2007; Giménez-García et al., 2007; Reynolds, 2004; Reynolds \& Biel, 2007; Reynolds \& Thompson, 2007; Giokas et al., 2015; Kukanja \& Planinc, 2018a; Parte \& Alberca, 2019). On the contrary, only in a few studies were the identified average scores below our results (Alberca \& Parte, 2018; Assaf et al., 2011; Hadad et al., 2007).

The comparison of results between our study and previous studies is difficult if not impossible since different inputs and outputs had been used in different DEA studies (see also Table 1). The direct comparison is possible only with the results of Kukanja and Planinc's (2018a) study; the authors had used the same inputs and output as they were used in our study and calculated the average efficiency of 142 restaurants at $85 \%$. In their study, restaurants were located predominantly in Slovenian urban areas, while in our case, restaurant facilities were located exclusively in rural areas. We can assume that restaurants in urban areas can generate higher revenues since urban areas offer a higher number and frequency of guests. Restaurants in urban areas are also more often characterised as more luxurious and can consequently charge higher prices for their offerings.

This research also has some other limitations that must be considered. DEA analysis is a deterministic method and, consequently, every observed unit that does not lie on the efficiency frontier is characterised as an inefficient unit (Fried, Knox Lovell, \& Schmidt, 1993). The financial data used in our study presented only one business year (2018). Therefore, it would be of great interest to use the panel data. Another limita- tion is concerned with the sample size and geographical distribution of restaurant facilities. It would be necessary to broaden the research in order to get more conclusive results of the analysis.

Regarding the practical implications of this study, we provided some valuable information for restaurant managers and decision-makers in terms of identifying areas where further optimisations are possible and necessary in order to improve restaurant firms' efficiency. The analysis revealed that managers should primarily focus on optimising labour costs. Unfortunately, we also determined that managers have little or no space for such optimisation because of the already low salaries in the restaurant industry and because of the strict labour and tax legislation. Therefore, an essential area for restaurants' operational efficiency improvement might be inter-firm networking, especially in terms of optimising the costs of goods and material sold and costs of material.

In order to ensure comparable benchmarking analyses, we should also emphasise the importance of the usage of objective and reliable information in determining the efficiency levels. Objective and reliable data is a prerequisite for conducting effective efficiency analyses.

For an in-depth understanding of restaurants' efficiency, further research is needed. Researchers should focus on analysing management practices of the bestperforming restaurants. In addition, the element of quality of input and output variables is also worth further investigation, since the use of appropriate variables is imperative in understanding the achieved efficiency levels.

Further research should consider incorporating firms' non-financial indicators into the efficiency analysis. Non-financial indicators are becoming increasingly important in evaluating the business performance and, in combination with financial indicators, represent a balanced scorecard consisting of four performance elements: financial, customer service, internal processes, and the learning and growth aspect $(\mathrm{Ka}-$ plan \& Norton, 1992). The fact is that relying solely on financial analysis is not advisable since companies are often able to tailor business results in one way or another (Atkinson \& Brown, 2001; Hansen, Otley, \& Van 
der Stede, 2003). The combination of financial and non-financial indicators is imperative in today's competitive environment. Many firms already use nonfinancial indicators related to customer satisfaction, product quality, achieved market share, corporate social responsibility, environmental indicators (e.g., carbon footprint, green practices, etc.), firms' organisational climate, etc. (Kaplan \& Norton, 1996; Tarigan \& Widjaja, 2012; Banker, Potter, \& Srinivasan, 2005; Sainaghi et al., 2017).

Since the restaurant industry is a vital part of the tourism industry, there is a need to establish a standardised selection of inputs and outputs. Ensuring an appropriate system for standardised efficiency analyses would significantly contribute to accurate benchmarking of the restaurant industry worldwide.

\section{References}

Alberca, P., \& Parte, L. (2018). Operational efficiency evaluation of restaurant firms. International Journal of Contemporary Hospitality Management, 3o(3), 1959-1977.

Assaf, A. G., \& Agbola, F. W. (2011). Modelling the performance of Australian hotels: A DE A double bootstrap approach. Tourism Economics, 17(1), 73-89.

Assaf, A. G., Deery, M., \& Jago, L. (2011). Evaluating the performance and scale characteristics of the Australian restaurant industry. Journal of Hospitality \& Tourism Research, 35(4), 419-436.

Assaf, A. G., \& Josiassen, A. (2016). Frontier analysis: A stateof-the-art review and meta-analysis. Journal of Travel Research, 55(5), 612-627.

Assaf, A. G., \& Matawie, K. M. (2009). A two-stage approach to efficiency modeling: An application to the Australian hospital food production industry. Journal of Hospitality \& Tourism Research, 33(3), 284-304.

Atkinson, H., \& Brown, J. B. (2001). Rethinking performance measures: Assessing progress in U K hotels. International Journal of Contemporary Hospitality Management, 13(3), 128-136.

Banker, R. D., \& Morey, R. C. (1986). Efficiency analysis for exogenously fixed inputs and outputs. Operations Research, 34(4), 513-521.

Banker, R. D., Potter, G., \& Srinivasan, D. (2005). Association of nonfinancial performance measures with the financial performance of a lodging chain. Cornell Hotel and Restaurant Administration Quarterly, 46(4), 394-412.

Barros, C. A. P. (2005). Measuring efficiency in the hotel sector. Annals of Tourism Research, 32(2), 456-477.
Barros, C. A. P., Dieke, P. U. C., \& Santos, C. M. (2010). Heterogeneous technical efficiency of hotels in Luanda, Angola. Tourism Economics, 16(1), 137-151.

Barros, C. A. P., \& Santos, C. A. (2006). The measurement of efficiency in Portuguese hotels using data envelopment analysis. Journal of Hospitality \& Tourism Research, 30(3), 378-400.

Barrows, C. W., Vieira, E. T., \& DiPietro, R. B. (2015). Increasing the effectiveness of benchmarking in the restaurant industry. International Journal of Process Management and Benchmarking, 6(1), 79-111.

Bélisle, F. J. (1983). Tourism and food production in the Caribbean. Annals of Tourism Research, 10(4), 497-513.

Bessière, J. (1998). Local development and heritage: Traditional food and cuisine as tourist attractions in rural areas. Sociologia Ruralis, 38(1), 21-34.

Bogetoft, P., \& Otto, L. (2011). Benchmarking with DEA, SFA, and $R$. New York, NY: Springer Science+Business Media.

Boyne, S. (2001). VFR (visiting friends and relatives) tourism in rural Scotland: A geographical case study analysis. In J. J. Lennon (Ed.), International perspectives on tourism statistics (pp. 125-136). London, England: Continuum International Publishers.

Boyne, S., Williams, F., \& Hall, D. (2002). On the trail of regional success: Tourism, food production and the Isle of Arran Taste Trail. In A.-M. Hjalager \& G. Richards (Eds.), Tourism and gastronomy (pp. 91-114). Abingdon, England: Routledge.

Briedenhann, J., \& Wickens, E. (2004). Tourism routes as a tool for the economic development of rural areas: Vibrant hope or impossible dream? Tourism Management, 25(1), 71-79.

Brown, J. R., \& Ragsdale, C. T. (2002). The competitive market efficiency of hotel brands: An application of data envelopment analysis. Journal of Hospitality \& Tourism Research, 26(4), 332-36o.

Choi, K. W., Roh, Y. S., \& Yoon, J.-H. (2007). An empirical examination of productivity of a chain restaurant using data envelopment analysis (DEA). International Journal of Quality and Productivity Management, 7(1), 47-67.

Coelli, T. J., Rao, D. S. P., O’Donnell, C. J., \& Battese, G. E. (2005). An introduction to efficiency and productivity analysis. New York, NY: Springer Science \& Business Media.

Dashper, K. (Ed.). (2014). Rural tourism: An international perspective. Newcastle upon Tyne, England: Cambridge Scholars.

Donthu, N., Hershberger, E. K., \& Osmonbekov, T. (2005). Benchmarking marketing productivity using data en- 
velopment analysis. Journal of Business Research, 58(11), 1474-1482.

Emrouznejad, A., \& Yang, G. (2018). A survey and analysis of the first 40 years of scholarly literature in DEA: 19782016. Socio-Economic Planning Sciences, 61(c), 4-8.

Fang, C.-Y., \& Hsu, F.-S. (2014). An efficiency-based metafrontier approach to menu analysis. Journal of Hospitality \& Tourism Research, 38(2), 199-221.

Farrell, M. J. (1957). The measurement of productive efficiency. Journal of the Royal Statistical Society, 120(3), 253290.

Fried, H. O., Knox Lovell, C. A., \& Schmidt, S. S. (Eds.) (1993). The measurement of productive efficiency: Techniques and applications. New York, NY; Oxford, England: Oxford University Press.

Fried, H. O., Knox Lovell, C. A., \& Schmidt, S. S. (Eds.) (2008). The measurement of productive efficiency and productivity growth. New York, NY: Oxford University Press, USA.

George, E. W., Mair, H., \& Reid, D. G. (Eds.). (2009). Rural tourism development: Localism and cultural change. Bristol, England: Channel View Publications.

Geografski terminološki slovar. (2013). Retrieved https:// isjfr.zrc-sazu.si/sl/terminologisce/slovarji/geografski\#v

Giménez-García, V. M., Martínez-Parra, J. L., \& Buffa, F. P. (2007). Improving resource utilization in multi-unit networked organizations: The case of a Spanish restaurant chain. Tourism Management, 28(1), 262-270.

Giokas, D., Eriotis, N., \& Dokas, I. (2015). Efficiency and productivity of the food and beverage listed firms in the prerecession and recessionary periods in Greece. Applied Economics, 47(19), 1927-1941.

Hadad, Y., Friedman, L., \& Hanani, M. Z. (2007). Measuring efficiency of restaurants using the data envelopment analysis methodology. Computer Modelling and New Technologies, 11(4), 25-35.

Hall, D., Roberts, L., \& Morag, M. (Eds.) (2016). New directions in rural tourism. Abingdon, England: Routledge.

Hansen, S. C., Otley, D. T., \& Van der Stede, W. A. (2003). Practice developments in budgeting. Journal of Management Accounting Research, 15(1), 95-116.

Hruschka, H. (1986). Ansätze der effizienzmessung von betrieben. Journal Für Betriebswirtschaft, 36(2), 76-85.

Kaplan, R. S., \& Norton, D. P. (1992). The balanced scorecard: Measures that drive performance. Harvard Business Review, $70(1), 71-79$.

Kaplan, R. S., \& Norton, D. P. (1996). Using the balanced scorecard as a strategic management system. Harvard Business Review, 74(1), 75-85.
Kukanja, M., \& Planinc, T. (2018a). Efficiency analysis of restaurants in a small economy after the implementation of fiscal cash registers: The case of Slovenia. Organizacija, 51(4), 239-253.

Kukanja, M., \& Planinc, T. (2018b). Influence of managers' perceptions of quality on restaurant operational profitability: Evidence from Slovenian smes. Turizam, 66(2), 115-129.

Lee, C., Hallak, R., \& Sardeshmukh, S. R. (2016). Innovation, entrepreneurship, and restaurant performance: $\mathrm{A}$ higher-order structural model. Tourism Management, 53, 215-228.

MacNulty, P. (2004). Establishing the principles for sustainable rural tourism. In Rural tourism in Europe: Experiences, development and perspectives (pp. 13-18). Madrid, Spain: World Tourism Organization.

Martić, M., Novaković, M., \& Baggia, A. (2009). Data envelopment analyiss: Basic models and their utilization. Organizacija, 42(2), 37-43.

Mhlanga, O. (2018). Factors impacting restaurant efficiency. Tourism Review, 73(1), 82-93.

Ministrstvo za kmetijstvo in okolje. (2013). Program razvoja podeželja Republike Slovenije za obdobje 2014-2020. Ljubljana, Slovenia: Ministrstvo za kmetijstvo in okolje.

Nigam, D., \& Narula, V. K. (Eds.) (2011). Rural tourism: Emerging issues and challenges. New Delhi, India: Shree Publishers \& Distributors.

OECD. (1994). Tourism strategies and rural development. Paris, France: Author.

Oliveira, R., Pedro, M. I., \& Marques, R. C. (2013). Efficiency and its determinants in Portuguese hotels in the Algarve. Tourism Management, 36, 641-649.

Parte, L., \& Alberca, P. (2019). A multistage model to evaluate the efficiency the bar industry. International Journal of Hospitality Management, 77, 512-522.

Pérez-Rodríguez, J. V., \& Acosta-González, E. (2007). Cost efficiency of the lodging industry in the tourist destination of Gran Canaria (Spain). Tourism Management, 28(4), 993-1005.

Planinc, T., Kukanja, M., \& Planinc, S. (2018). Classification and efficiency analysis of Slovenian restaurant SMES. Academica Turistica, 11(1), 31-42.

Poldrugovac, K., Tekavcic, M., \& Jankovic, S. (2016). Efficiency in the hotel industry: An empirical examination of the most influential factors. Economic Research, 29(1), 583-597.

Reynolds, D. (2003). Hospitality-productivity assessment: Using data-envelopment analysis. Cornell Hotel and Restaurant Administration Quarterly, 44(2), 130-137. 
Reynolds, D. (2004). An exploratory investigation of multiunit restaurant productivity assessment using data envelopment analysis. Journal of Travel \& Tourism Marketing, 16(2/3), 19-26.

Reynolds, D., \& Biel, D. (2007). Incorporating satisfaction measures into a restaurant productivity index. International Journal of Hospitality Management, 26(2), 352-361.

Reynolds, D., \& Taylor, J. (2011). Validating a DEA-based menu analysis model using structural equation modeling. International Journal of Hospitality Management, $30(3), 584-587$.

Reynolds, D., \& Thompson, G. M. (2007). Multiunit restaurant productivity assessment using three-phase data envelopment analysis. International Journal of Hospitality Management, 26(1), 20-32.

Riley, M. (1999). Re-defining the debate on hospitality productivity. Tourism and Hospitality Research, 1(2), 182186.

Roberts, L., \& Hall, D. (2001). Rural tourism and recreation: Principles to practice. Wallingford, England: CA B I Publishing.

Roh, E. Y., \& Choi, K. (2010). Efficiency comparison of multiple brands within the same franchise: Data envelopment analysis approach. International Journal of Hospitality Management, 29(1), 92-98.

Sainaghi, R., Phillips, P., \& Zavarrone, E. (2017). Performance measurement in tourism firms: A content analytical meta-approach. Tourism Management, 59(2017), $36-56$.

Sedmak, G., Planinc, T., \& Planinc, S. (2011). Unexploited potentials of networking in the hospitality businessSlovenia's Case. Tourism and Hospitality Management, $17(2), 187-200$.
Sharpley, R., \& Sharpley, J. (1997). Rural tourism: An introduction. London, England: International Thomson Business Press.

Tarigan, D., Josua, \& Widjaja, D. C. (2012). The relationship between non-financial performance and financial performance using balanced scorecard. International Journal of Innovation, Management and Technology, 3(5), 614-618.

Taylor, J., Reynolds, D., \& Brown, D. M. (2009). Multi-factor menu analysis using data envelopment analysis. International Journal of Contemporary Hospitality Management, 21(2), 213-225.

Wöber, K. W. (2007). Data envelopment analysis. Journal of Travel \& Tourism Marketing, 21(4), 91-108.

W T T C. (2019a). Travel\&Tourism economic impact 2018 Slovenia. London, England: Author.

W T TC. (2019b). Travel\&Tourism economic impact 2019 World. London, England: Author.

Zakon o spremembah in dopolnitvah Zakona o gostinstvu (zGOs-B) (2005). Uradni list Republike Slovenije, No. 101, 10613-10618.

Zupančič, J. (2019, 3 August). Država ima slab marketing: pri nas ni vse slabo in drago. Retrieved from https:/www .vecer.com/intervju-drzava-ima-slab-marketing-pri -nas-ni-vse-slabo-in-drago-10048179

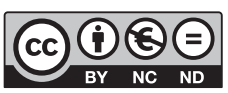

This paper is published under the terms of the Attribution- NonCommercial-NoDerivatives 4.0 International (CC BY-NC-ND 4.0) License. 